\title{
Mesobuthus eupeus SCORPIONISM IN SANLIURFA REGION OF TURKEY
}

\section{OZKAN O. (1), KAT I. (2)}

(1) Refik Saydam Hygiene Center, Poison Research Center, Turkey; (2) Department of Infectious Diseases, Health Center of Sanliurfa, Turkey.

ABSTRACT: The epidemiology and clinical findings of scorpion stings in Sanliurfa region of Turkey, from May to September 2003, were evaluated in this study. Mesobuthus eupeus (M. eupeus) plays a role on $25.8 \%$ of the scorpionism cases. This study also showed that intoxications caused by $M$. eupeus in the southeast of Anatolia region were seen in hot months of the summer, especially on July. Females and people above 15 years old were mostly affected and stung on extremities. Intense pain in the affected area was observed in $98.7 \%$ cases, hyperemia in $88.8 \%$, swelling in $54.6 \%$, burning in $19.7 \%$, while numbness and itching were seen less frequently. In our study, the six most frequently observed symptoms were local pain, hyperemia, swelling, burning, dry mouth, thirst, sweating, and hypotension. In this study involving $152 \mathrm{M}$. eupeus toxicity cases, patients showed local and systemic clinical effects but no death was seen. Autonomic system and local effects characterized by severe pain, hyperemia and edema were dominantly seen in toxicity cases.

KEY WORDS: Mesobuthus eupeus, Turkey, scorpionism, epidemiology, clinical symptoms.

\section{CORRESPONDENCE TO:}

OZCAN OZKAN, Veterinary Medicine Laboratory, Refik Saydam Hygiene Center, Poison Research Center, 06100 Ankara, Turkey. Email: ozcanozkan62@hotmail.com 


\section{INTRODUCTION}

Envenomation by arachnids causes significant medical illness worldwide. The most important cause of arachnid morbidity is scorpion sting (37).

Scorpion venoms contain a group of neurotoxins, which have been shown to interact with ionic channels in excitable membranes, and contain some peptides, enzymes, amines and proteases with various effects $(10,24,40,53,54)$. Several studies on scorpion sting cases emphasized that various clinical signs were seen, ranging from local symptoms to serious autonomic and central nervous system symptoms, and also death due to cardio and respiratory failure, especially in children $(1,9,19,23$, $25,34,41,44,47)$.

Scorpion envenomation is an important public health problem in tropical and subtropical regions $(29,31,35,38,46,52)$. Among 1500 species described, 50 present dangerous venoms for humans, and most of these species belong to the genera Buthus, Parabuthus, Mesobuthus, Tityus, Leiuris, Androctonus, Centruroides of the Buthidae family $(39,41,45,52)$. Among these species, Tityus serrulatus and $T$. bahiensis are common and lethal scorpion species in South America, especially in Brazil; Centruroides suffusus, C. limpidus, and C. sculpturatus in Mexico; Leiurus quinquestriatus, Androctonus crassicauda, A. mauretanicus, A. australis, A. amoreuxi, and Buthus occitanus in the Middle East and North Africa countries; Parabuthus granulatus and $P$. transvaalicus in South Africa countries; Mesobuthus tamulus and Palamneus swammerdami in India $(5,6,7,22,30,33,36,42,45$, 49).

Scorpions and human envenomation cases are common in Turkey due to its geographical location, climate and socioeconomic structure. Scorpion envenomation is an important health problem in all regions, especially in Southeastern Anatolia (38, 41). Important scorpions threatening public health in Turkey are $A$. crassicauda, $L$. quinquestriatus, Mesobuthus gibbosus and M. eupeus of the family Buthidae (38, 41).

Several studies reported that the scorpion species $A$. crassicauda was common in Southeastern Anatolia region, especially in Sanliurfa and Mardin provinces; $M$. gibbosus in Aegean and Middle Anatolia regions; M. eupeus in Eastern and Southeastern Anatolia regions; and L. quinquestriatus only in Adiyaman province (38, 51). 
This study aims to evaluate the epidemiology and clinical findings of scorpionism in Sanliurfa, a province in the Southeast of Turkey.

\section{MATERIALS AND METHODS}

This prospective study was based on 598 subjects from Sanliurfa city and surrounding villages who were admitted to the provincial healthcare facilities in Sanliurfa with scorpion stings from May 1, 2003 to the first week of September 2003. A questionnaire was distributed to physicians in provincial healthcare facilities to collect patient data (name, age, sex, scorpion identification [scorpion color], date of sting, sting location in the body, and clinical manifestations). Scorpion identification was made according to the scorpion color defined by the patient.

This study was carried out based on 152 patients with complaint of yellow scorpion (M. eupeus) sting. Data obtained from the questionnaires about these patients were analyzed with SPSS software, using analysis of Pearson's chi-square method. Values obtained were considered to be significantly different if $p<0.05$.

\section{RESULTS}

From the total, $152(25.8 \%)$ cases were reported as yellow scorpion stings; within the scope of the study, laboratory identification of these species was not carried out, however literature data shows that $M$. eupeus, known as yellow scorpion, inhabits Sanliurfa region $(21,26,27,38)$. In $138(23.4 \%)$ of the total cases, patients could not distinguish the color of the scorpions involved.

The distribution of the scorpion sting cases according to month of sting, sex of the patient and sting site is given in table 1. The table shows that 142 (93.4\%) out of 152 scorpionism cases took place in the summer period; the month distribution was June (45.4\%), July (25.0\%), and August (23.0\%). Seven (4.6\%) of the cases occurred in May and three $(2.0 \%)$ in September.

It is also shown in the table that women were more liable to scorpion sting than men, being reported $59.2 \%$ cases for women and $40.8 \%$ for men. With respect to the age, it was shown that the 15-29 age group presented more scorpion sting $(36.2 \%)$ than the other groups; the distribution being $25.0 \%$ for the $0-14$ age group, $24.3 \%$ for the $30-44$ age group, and $14.5 \%$ for the $>45$ age group.

The sting sites in the body given in the table are $43.4 \%$ for upper extremities and $38.2 \%$ for lower extremities. 
Analysis of the data in records of the healthcare organization of Sanliurfa province alarmed that the local and systemic symptoms were manifested. In the 152 scorpionism cases caused by $M$. eupeus, the local symptoms were pain, hyperemia, swelling, burning, itching, and numbness in the ratio of $98.7 \%, 88.8 \%, 54.6 \%, 19.7 \%$, $2.0 \%$, and $0.7 \%$, respectively. The differences in the local symptoms with respect to age groups, sex, month, and sting site were not statistically significant ( $p>0.05)$.

The records of the healthcare organizations have also shown that the systemic symptoms in the $152 \mathrm{M}$. eupeus scorpionism cases were, in general, dry mouth $(8.6 \%)$, thirst $(5.9 \%)$, sweating $(5.3 \%)$, hypotension $(3.9 \%)$, nausea $(2.0 \%)$, hypertension $(1.3 \%)$, difficulty in breathing $(1.3 \%)$, tachycardia $(0.7 \%)$, increase of bronchial secretion $(0.7 \%)$, and cyanosis $(0.7 \%)$. The differences in the systemic symptoms with respect to age groups, sex, month, and sting site were not statistically significant $(p>0.05)$. 
Table 1: Distribution of the scorpion sting cases according to the scorpion color, month of sting, patients' sex and age, sting site, local and systemic symptoms.

\begin{tabular}{|c|c|c|}
\hline Scorpion color & Number of patients $(n=598)$ & $\%$ \\
\hline Black & 299 & 50.8 \\
\hline Yellow & 152 & 25.8 \\
\hline Unknown & 138 & 23.4 \\
\hline Months & Number of patients $(n=152)$ & $\%$ \\
\hline May & 7 & 4.6 \\
\hline June & 69 & 45.4 \\
\hline July & 38 & 25.0 \\
\hline August & 35 & 23.0 \\
\hline September & 3 & 2.0 \\
\hline Patient's sex & Number of patients $(n=152)$ & $\%$ \\
\hline Female & 90 & 59.2 \\
\hline Male & 62 & 40.8 \\
\hline Age groups & Number of patients $(n=152)$ & $\%$ \\
\hline $0-14$ & 38 & 25.0 \\
\hline $15-29$ & 55 & 36.2 \\
\hline $30-44$ & 37 & 24.3 \\
\hline$>44$ & 22 & 14.5 \\
\hline Sting site & Number of patients ( $n=152)$ & $\%$ \\
\hline Upper extremity & 66 & 43.4 \\
\hline Lower extremity & 58 & 38.2 \\
\hline Body & 19 & 12.3 \\
\hline Head and Neck & 9 & 5.9 \\
\hline Local symptoms & Number of patients $(n=152)$ & $\%$ \\
\hline Pain & 150 & 98.7 \\
\hline Hyperemia & 135 & 88.8 \\
\hline Swelling & 83 & 54.6 \\
\hline Burning & 30 & 19.7 \\
\hline Numbness & 1 & 0.7 \\
\hline Itching & 3 & 2.0 \\
\hline Systemic symptoms & Number of patients $(n=152)$ & $\%$ \\
\hline Dry mouth & 13 & 8.6 \\
\hline Thirst & 9 & 5.9 \\
\hline Sweating & 8 & 5.3 \\
\hline Nausea & 3 & 2.0 \\
\hline Dyspnea & 2 & 1.3 \\
\hline Cyanoses & 1 & 0.7 \\
\hline İncrease of bronchial secretion & 1 & 0.7 \\
\hline Hypotension (n=65) & 6 & 3.9 \\
\hline Hypertension (n=65) & 2 & 1.3 \\
\hline Tachycardia $(n=70)$ & 1 & 0.7 \\
\hline
\end{tabular}




\section{DISCUSSION}

Scorpions are arthropods, their lengths range from 13 to $220 \mathrm{~mm}$, and they are easily recognizable because of their morphological structures $(39,41)$. Scorpions live mostly under ruins and stones during the day because they have no tolerance to high temperatures in hot seasons, by this way they protect themselves from high temperatures $(32,38,39,41,50)$.

All scorpion species with highly potent, mammal-specific neurotoxins belong to the family Buthidae, which therefore has medical importance (20). Mesobuthus eupeus is a member of Mesobuthus genus, Buthidae family. Some genera of this family like Tityus, Centruroides, Androctonus, and Parabuthus are known for their strong neurotoxins (45). Mesobuthus eupeus has a wide geographic distribution in Middle East and Central Asia and is responsible for a large number of envenomations in those regions $(27,45)$.

The first records of $M$. eupeus in Turkey were given by Birula (8) in Artvin, Kars, and Oltu (Erzurum). Kinzelbach (28) reported some new localities in eastern and southeastern Anatolia. Crucitti (11, 12, 13), and Crucitti and Cicuzza (14, 15, 16) found this species in Adiyaman, Agri, Kars and Van, and also suggest the first locality as the possible westernmost site in the species range. However, Karatas and Karatas (26) and Teruel (48) gave new distributional localities westward, first for Nigde and then for Manisa provinces, reporting the species for the first time in central and northwestern Anatolia, respectively $(26,27)$. Karatas and Karatas (26) recently reported that $M$. eupeus commonly occurs in eastern (Elazig, Erzurum, Kars, Bingol, Van), southeastern (Sanliurfa, Viransehir, Büyükbardakçi Village, Mardin, Adiyaman, Hatay) and central Anatolia (Nigde, Konya, Kayseri), and it also ranges westward towards the Aegean Sea, but it does not reach the coastal region of Anatolia (26, 27, 38).

Scorpions become active at night and sting for their own protection against humans $(32,38)$. There were no epidemiological and clinical researches about the importance of $M$. eupeus stings in Turkey until now. In our study, 598 scorpion sting cases seen in Sanliurfa during one season were investigated, in which patients had medical care and were followed in healthcare facilities.

This study shows that $25.8 \%$ of all cases was affected by $M$. eupeus. This percentage is $45 \%$ in Iran (43). Radmanesh (43) published that there were many scorpion stings in the urban region during hot seasons, and especially child deaths 
were seen due to scorpion toxicities in Iran (43). In a similar way, most scorpionism cases were seen during summer time in Brazil, Saudi Arabia, Egypt and Morocco, when compared to the other months $(2,17,19,23,32,42)$. In this research, most of the scorpion stings (93.4\%) were seen in the summer months, when the temperature was $40-45^{\circ} \mathrm{C}$; the month distribution being $45.4 \%, 25.0 \%$ and $23.0 \%$ in July, June and August, respectively.

Dittrich stated that children below 5 years old and $20-25 \%$ of infants showed widespread hyperemia and most of the children below 11 years old showed hypertension. Irritability with central nervous system effects was seen in most of the children and infants (18). In our study, we did not separate age groups since we obtained similar results like $0-5$ and $0-14$ age groups. The literature data state that, in Morocco, the 15-29 age group was influenced the most by scorpion stings and ages over 44 were influenced the least (23). In this study, similar results were found for the same age groups. In Saudi Arabia $(2,23)$, scorpion stings have been mostly seen in patients aged 15 and over. In our study, we have obtained similar results. The reason for this is that the young population in this region works in agricultural fields and collects scorpions for economic reasons.

Epidemiological studies have shown that the ratio of patients affected in the extremities (hand, arm, leg, thigh, foot) is $86 \%$ in Saudi Arabia (2), $83 \%$ in Argentina (17) and $85 \%$ in Egypt (19). In this study, $81.6 \%$ of the patients had scorpion stings in their extremities such as hand, arm, leg, thigh and foot. Scorpion sting was mostly seen in the upper limbs in Morocco $(23,50)$ and Brazil $(42)$; similar results were found in our study. The reason for the high ratio of scorpion sting in extremities is considered to be due to the socioeconomic structure depending on agriculture in rural areas of Sanliurfa province, to wearing sandals in warm season, walking barefoot (especially children), putting on shoes without pre-shaking, hand searching for scorpions in their homes, lifting up stones in controlled manner, shaking the hands during sleep or resting to move away scorpions. Stings in the head, neck and other sites of the body mostly happened at sleep or resting because of putting on clothes without checking and also not controlling bed mattresses.

In Tunisia (1), Egypt (19) Saudi Arabia (2), Argentina (17) and Brazil (42), epidemiological studies showed that most scorpion stings were seen in males, but in our study this was different. The analysis of data showed that both in the total cases and in the monthly data, scorpion stings were seen mostly in females. It is thought 
that females have a high percentage when compared with males in population. Bergman (7) reported that scorpion stings were seen mostly in females in Zimbabwe (7). However, in a research carried out in two different regions of Morocco, scorpion stings in southwest regions (50) were high in males, and in El-Kala, El-Jadida, Agdir and Tan-Tan regions (23) it was high in females. This helps to realize that malefemale distribution shows differences according to region as seen in our study.

Toxicity of venom changes according to regions and scorpion species (4). Because of that, in toxicities due to scorpion stings, local or systemic clinical effects could be related to the scorpion species, feeding state, structure and amount of venom, number of stings, patient's sensitivity, age and weight, climate of the region, and first medical aid $(3,17,18,37,43)$. The scorpion venom can cause a variety of symptoms, from pain at the sting site to death (52). In this study involving $152 \mathrm{M}$. eupeus toxicity cases, patients showed local and systemic clinical effects, but no death was seen since first medical aid and treatment (antivenom and symptomatic treatment) were effective.

Scorpion venoms cause direct effect and release of neurotransmitters, such as acetylcholine and catecholamines, which produce signs of autonomic system overactivity or autonomic storms $(49,52)$. Radmanesh stated that, related to dose of venom, sympathetic activation in low doses and parasympathetic activation in high doses would appear, and the clinical effects were characterized mostly by pain due to venom at low concentrations because it could not stimulate acetylcholine receptors above threshold (43).

As shown in Table 1, intense pain in the affected area was observed in $98.7 \%$ of cases, hyperemia in $88.8 \%$, swelling in $54.6 \%$, burning in $19.7 \%$, while numbness and itching were seen less frequently. In our study, the six most frequently observed symptoms were: local pain, hyperemia, swelling, burning, dry mouth, thirst, sweating, and hypotension.

Affected autonomic system together with local effects characterized by severe pain, hyperemia and edema were dominant in toxicity cases.

Results of this study showed that intoxications caused by $M$. eupeus in southeast Anatolia region were seen in the summer and in hot months, especially in July. Females and people above 15 years old were mostly affected and stung in the upper and lower extremities. In clinical evaluations, we observed systemic effects and no death, and also parasympathetic effects were superior to sympathetic effects. 
In many cases, the patients were stung by scorpions due to their lack of knowledge and carelessness such as in putting their hands into scorpion homes, walking barefoot, lifting up stones carelessly, and putting on their clothes and shoes without shaking them to check for scorpions.

As a result, people living in those regions where most scorpion stings were seen must be educated and informed about scorpions and their stings.

\section{REFERENCES}

1 ABROUG F., ELATROUS S., NOUIRA S., HAGUIGA H., TOUZI N., BOUCHOUCHA S. Serotherapy in scorpion envenomation: a randomised controlled trial. Lancet, 1999, 354, 906-9.

2 AL-SADOON MK., JARRAR BM. Epidemiological study of scorpion stings in Saudi Arabia between 1993 and 1997. J. Venom. Anim. Toxins incl. Trop. Dis., 2003, 9, 54-64.

3 ALTINKURT O., ALTAN M. Pharmacological effects of the scorpion (Androctonus crassicauda) venom from urfa enviroment on laboratory animals and the antagonistic effects of streptomycin to most of these effects. Ankara Ecz. Fak. Derg., 1980, 10, 41-60.

4 AMARAL CFS., REZENDE NA. Treatment of scorpion envenoming should include both a potent specific antivenom and support of vital functions. Toxicon, 2000, $38,1005-7$.

5 BALOZET L. Scorpionism in the Old World. In: BÜCHERL W., BUCKLEY EE. Eds. Venomous animals and their venoms. New York: Academic Press, 1971: 34971.

6 BELGHITH M., BOUSSARSAR M., HAGUIGA H., BESBES L., ELATROUS S., TOUZI N., BOUJDARIA R., BCHIR A., NOUIRA S., BOUCHOUCHA S., ABROUG F. Efficacy of serotherapy in scorpion sting: a matched-pair study. $J$. Toxicol. Clin. Toxicol., 1999, 37, 51-7.

7 BERGMAN NJ. Clinical description of Parabuthus transvaalicus scorpionism in Zimbabwe. Toxicon, 1997, 35, 759-71.

8 BIRULA, A. [BYALYNITSKII-BIRULYA, A.A.] Chlenistobryukhie paukoobraznye Kavkazskogo Kraya [Arthrogastric arachnids of Caucasia]. Part I. Scorpiones. Tiflis: Mémoires du Musée du Caucase, Sér. A 1917, 5: 1-253. [English translation: Jerusalem: Israel Program for Scientific Translation,1964]. 
9 BLUM A., JAWABREH S., GUMANOVSKY M., SOBOH S. Scorpion envenomation and myocardial damage. Isr. Med. Assoc. J., 2000, 2, 318-9.

10 CONDE R., ZAMUDIO FZ., RODRIGUEZ MH., POSSANI LD. Scorpine, an antimalaria and anti-bacterial agent purified from scorpion venom. FEBS Lett., 2000, 471, 165-8.

11 CRUCITTI, P. Some topics on distribution patterns of the genus Mesobuthus in the Near East based on ecological data (Scorpiones: Buthidae). Biol. GalloHell., 1993, 20: 69-74.

12 CRUCITTI, P. The scorpions of Anatolia: Biogeographical patterns. Biogeographica, 1999, 20: 81-94.

13 CRUCITTI, P. Scorpioni e scorpionismo nella Provincia di Adiyaman (Turchia Sud-orientale). Biologi Italiani, 2000, 6: 17-20.

14 CRUCITTI, P. \& D. CICUZZA. Gli Scorpioni del Parco Nazionale del Monte Nemrut (Turchia sudorientale) (Scorpiones). Memorie della Soc. Entomol. Ital., 2000, 78(2): 275-294.

15 CRUCITTI, P. \& D. CICUZZA. Scorpions of Anatolia: Ecological patterns. 2001a, Pp. 225-234 in Fet, V.\& P.A. Selden (eds.). Scorpions 2001: In Memoriam Gary A. Polis. Burnham Beeches, Bucks: British Arachnological Society.

16 CRUCITTI, P. \& D. CICUZZA. Ricerche bioecologiche su Mesobuthus eupeus del Monte Ararat (Turchia orientale) (Scorpiones Buthidae). Bollettino della Soc. Entomol. Ital., 2001b, 133(1): 3-11.

17 DE ROODT AR., GARCIA SI., SALOMON OD., SEGRE L., DOLAB JA., FUNES RF., DE TITTO EH. Epidemiological and clinical aspects of scorpionism by Tityus trivittatus in Argentina. Toxicon, 2003, 41, 971-7.

18 DITTRICH K., POWER AP., SMITH NA. Scorpion sting syndrome - a ten year experience. Ann. Saudi Med., 1995, 15, 148-55.

19 FARGHLY WMA., ALI FA. A clinical and neurophysiological study of scorpion envenomation in Assiut, Upper Egypt. Acta Paediatr., 1999, 88, 290-4.

20 FET V., GANTENBEIN B., GROMOV AV., LOWE G., LOURENÇO WR. The first molecular phylogeny of Buthidae (Scorpiones). Euscorpius, 2003, 4, 1-12.

21 FET V., MATT EB., BRAUNWALDER ME. The scorpions (Arachnida: scorpiones) of the Aegean area: current problems in taxonomy and biogeography. Belg. J. Zool., 2000, 130, 17-22. 
O. Ozkan and I. Kat. Mesobuthus eupeus SCORPIONISM IN SANLIURFA REGION OF TURKEY. J. Venom. Anim. Toxins incl. Trop. Dis., 2005, 11, 4, p. 489

22 GAJRE G., DAMMAS AS. Scorpion envenomation in children: should all stings be given antivenom? Ann. Saudi Med., 1999, 19, 444-6.

23 GHALIM N., EL-HAFNY B., SEBTI F., HEIKEL J., LAZAR N., MOUSTANIR R., BENSLIMANE A. Scorpion envenomation and serotherapy in Morocco. Am. J. Trop. Med. Hyg., 2000, 62, 277-83.

24 INCEOGLU B., LANGO J., WU J., HAWKINS P., SOUTHERN J., HAMMOCK BD. Isolation and characterization of a novel type of neurotoxic peptide from the venom of South African scorpion Parabuthus transvaalicus (Buthidae). Eur. J. Biochem., 2001, 268, 5407-13.

25 ISBISTER GK., GRAUDINS A., WHITE J., WARREL D. Antivenom treatment in arachnidism. J. Toxicol. Clin. Toxicol., 2003, 41, 291-300.

26 KARATAS A., KARATAS A. First record of Mesobuthus eupeus (C. L. Koch, 1839) (Scorpiones: Buthidae) from central Anatolia. In: FET V., SELDEN PA. Eds. Scorpions 2001 in memorian Gary A. Polis. United Kingdon: British Arachnological Society, 2001: 297-9.

27 KARATAS A., KARATAS A. Mesobuthus eupeus (C. L. Koch, 1839) (Scorpiones: Buthidae) in Turkey. Euscorpius, 2003, 7, 1-6.

28 KINZELBACH, R. Die Skorpionssammlung des Naturhistorischen Museums der Stadt Mainz. Teil II:Vorderasien. Mainzer Naturwisserschaftiches Archiv, 1984, 22: 97-106. Euscorpius - 2003, No. 76

29 KRIFI MN., MARRAKCHI N., EL-AYEB M., DELLAGI K. Effect of some variables on the in vivo determination of scorpion and viper venom toxicities. Biologicals, 1998, 26, 277-88.

30 LIRA-DA-SILVA RM., AMORIM AM., BRAZIL TK. Envenomation by Tityus stigmurus (Scorpiones: Buthidae) in Bahia, Brazil. Rev. Soc. Bras. Med. Trop., 2000, 33, 239-45.

31 LOURENÇO WR., CUELLAR O. Scorpions, scorpionism, life history strategies and parthenogenesis. J. Venom. Anim. Toxins, 1995, 1, 51-52.

32 MAHABA HMA. Scorpion sting syndrome: epidemiology, clinical presentation and management of 2240 cases. East. Mediterr. Health J., 1997, 3, 82-9.

33 MAHADEVAN S. Scorpion sting. Indian Pediatr., 2000, 37, 504-14.

34 MAZZEI DE DAVILA CA., PAARA M., FEUNMAYOR A., SALGAR N., GONZALEZ Z., DAVILA DF. Scorpion envenomation in Merida, Venezuela. Toxicon, 1997, $35,1459-62$. 
35 MEDDEB-MOUELHI F., BOUHAOUALA-ZAHAR B., BENLASFAR Z., HAMMADI M., MEJRI T., MOSLAH M., KAROUI H., KHORCHANI T., EL AYEB M. Immunized camel sera and derived immunoglobulin subclasses neutralizing Androctonus australis hector scorpion toxins. Toxicon, 2003, 42, 785-91.

36 MULLEN G., STOCKWELL SA. Scorpions (Scorpiones). In: MULLEN G., DURDEN L. Eds. Medical and Veterinary Entomology. Amsterdam: Academic Press, 2002: 411-23.

37 OSNAYA-ROMERO N., DE JESUS MEDINA HERNANDEZ TJ., FLORESHERNANDEZ SS., LEON-ROJAS G. Clinical symptoms observed in children envenomated by scorpion stings, at the children's hospital from the State of Morelos, Mexico. Toxicon, 2001, 39, 781-5.

38 OZKAN O., KARAER Z. The scorpions in Turkey. Turk. Hij. Deney. Biyol. Derg., 2003, 60, 55-62.

39 OZKAN O., KARAER Z. Body structures of scorpions. Acta Parasitol. Turcica, 2004, 28, 54-8.

40 OZKAN O., YAMAN N. Akrep zehiri. Ankara Bölgesi Veteriner Hekimler Odasi, Bülten, Subat, 2004a, 19-22.

41 OZKAN O., YAMAN N. Akrep. Ankara Bölgesi Veteriner Hekimler Odasi, Bülten, Kasim, 2004b, 15-8.

42 PARDAL PP., CASTRO LC., JENNINGS E., PADAL JS., MONTEIRO MR. Epidemiological and clinical aspects of scorpion envenomation in the region of Santarém, Pará, Brazil. Rev. Soc. Bras. Med. Trop., 2003, 36, 349-53.

43 RADMANESH M. Androctonus crassicauda sting and its clinical study in Iran. J. Trop. Med. Hyg., 1990, 93, 323-6.

44 REEVES JJ. Scorpion envenomation. Clin. Toxicol. Rev., 1998, 20 [cited 2004 Nov 24]. Available from: http://www.maripoisoncenter.com/ctr/9803scorpion.html.

45 SADEGHIAN $\mathrm{H}$. Transient ophtalmoplegia following envenomation by the scorpion Mesobuthus eupeus. Neurology, 2003, 60, 346-7.

46 SEDDIK SS., WANAS S., SHEHATA A., FAWAZ S., HELMY MH. Development of an improved method for production of antiscorpion $F(a b)_{2}$ fragment of $\lg G$ with high yield and potency. J. Nat. Toxins, 2002, 11, 123-32.

47 SOFER S., SHAHAK E., GUERON M. Scorpion envenomation and antivenom therapy. J. Pediatr., 1994, 124, 973-8. 
48 TERUEL, R. First record of Mesobuthus eupeus (Koch, 1839) from western Turkey (Scorpiones:Buthidae). Rev. Iber. Aracnol., 2002, 5: 75-76.

49 THEAKSTON RDG., WARREL DA., GRIFFITHS E. Report of a WHO workshop on the standardization and control of antivenoms. Toxicon, 2003, 41, 541-57.

50 TOULOUN O., SLIMANI T., BOUMEZZOUGH A. Epidemiological survey of scorpion envenomation in southwestern Morocco. J. Venom. Anim. Toxins, 2001, 7, 199-218.

$51 \mathrm{VACHON} \mathrm{M.} \mathrm{A} \mathrm{propos} \mathrm{de} \mathrm{quelques} \mathrm{scorpions} \mathrm{de} \mathrm{Turquie} \mathrm{collectés} \mathrm{par} \mathrm{Mr.} \mathrm{Le}$ Professeur Dr. Curt Kosswig. Rev. Fac. Sci. Iniv. Istanbul, 1951, 16, 361-4.

52 VATANPOUR $\mathrm{H}$. Effects of black scorpion Androctonus crassicauda venom on striated muscle preparation in vitro. Iranian J. Pharm. Res., 2003, 2, 17-22.

53 WUDAYAGIRI R., INCEOGLU B., HERRMANN R., DERBEL M., CHOUDARY PV., HAMMOCK BD. Isolation and characterization of a novel lepidopteranselective toxin from the venom of South Indian red scorpion, Mesobuthus tamulus. BMC Biochem., 2001, 2, 16.

54 ZLOTKIN E., MIRANDA F., ROCHAT H. Chemistry and pharmacology of Buthinae scorpion venoms. In: BETTINI S. Ed. Arthropods venoms. Berlin: Springer Verlag, 1978: 317-69. 